\title{
Cervical cancer management in Zaria, Nigeria
}

\author{
Sa'adatu T. Sule ${ }^{*}$, Mohammed S. Shehu² \\ 1. Department of Obstetrics and Gynaecology, Ahmadu Bello University Teaching Hospital, Zaria, Nigeria; 2. \\ Department of Pathology, Ahmadu Bello University Teaching Hospital, Zaria, Nigeria. Email: \\ msshehu2@yahoo.com. Telephone: 234-802-3581782
}

Author for Correspondence: Sa'adatu T. Sule, Department of Obstetrics and Gynecology, Ahmadu Bello University Teaching Hospital, Zaria, Nigeria. Email: saasule@yahoo.com; Telephone: 234-803-4000676

\section{SUMMARY}

The paper's objective was to identify factors influencing cervical cancer management in Zaria with a view to improving the outcome of management. Case notes of patients managed for cervical cancer in Ahmadu Bello University Teaching Hospital (ABUTH), Zaria between January 11999 and December 31 2003, were retrieved and relevant information extracted and analyzed using MINITAB statistical software. There were 70 women with cervical cancer managed during the study period and their mean age was 47.61 years. Risk factors included high parity (mean $=\mathbf{7 . 4}$ ), low age at first coitus $($ mean $=\mathbf{1 4 . 6 2}$ years), multiple sex partners $(81.63 \%$ in polygamous marriages, $42.55 \%$ with multiple marriages), and smoking $(\mathbf{1 5 . 0 9 \% )}$. Poor prognostic factors included delayed presentation - mean duration of symptoms was 12.59 months and only $4.35 \%$ presented with stage I disease. Lack of funds for investigations and treatment was also a risk factor for poor prognosis (only $25 \%$ of the 24 patients who needed blood transfusion were adequately transfused and only $21.74 \%$ of all patients had complete treatment). The paper concludes that increased public awareness about cervical cancer is needed to minimise risk factors and encourage early presentation. Governments and other funding agencies need to devote more funds for cervical cancer prevention, screening and treatment.

(Afr J Health Sci. 2007; Vol 14: 149-153)

\section{Introduction}

Cervical cancer is a major health problem among women in most developing countries [1]. It is the commonest female genital tract malignancy and a major cause of morbidity and mortality among women in Nigeria $[2,3,4]$ and other sub-Saharan African countries [5, 6, 7]. The morbidity and mortality arising from cervical cancer can be minimized in these countries through effective screening and public awareness programs as has been done in most developed countries [1]. This will ensure that the diagnosis is made early enough for effective treatment as late presentation is one of the reasons why developing countries have high mortality rates from this condition. Public awareness programs will also play an important role in prevention by reducing risk factors.

Radiotherapy plays a major role in the treatment of cervical cancer especially the later stages with which women in this environment usually present [8]. However, the availability of facilities for radiotherapy and the cost of treatment is a limiting factor for most women who need the services in these resource-constrained developing countries including Nigeria [9]. Other supportive treatment such as blood transfusion may also limit the treatment of cervical cancer because of financial considerations. The radiotherapy unit at the Ahmadu Bello University Teaching Hospital, Zaria serves as a referral centre for most cervical cancer patients in northern Nigeria. However, the patients have to be first seen at the Gynaecology clinic for investigation and preparation for the treatment before being referred to the Radiotherapy unit. There is a possibility that costs of travel to Zaria may also influence the outcome of management as patients may have expended a lot of resources on travel thus limiting the available resources for investigations and treatment. This study was carried out to identify factors that influence cervical cancer management in this centre with a view to finding ways to improve its management.

\section{Methods}

All case notes for patients managed for cervical cancer in Ahmadu Bello University Teaching 
Hospital (ABUTH), Zaria between January 11999 and December 31 2003, were retrieved from the Gynaecology ward and clinic and the Radiotherapy/Oncology clinic. Information about the biosocial and clinical factors was extracted from the case notes and analysed using MINITAB statistical software. Cases of suspected cervical cancer that were not confirmed histologically were excluded from the analyses. Although surgery is an available treatment option, most cases of cervical cancer in this centre present late and are therefore treated with internal caesium radiotherapy (brachytherapy). Patients are considered unfit for radiotherapy if they have anaemia, renal or liver function derangement observed from baseline laboratory tests. Packed cell volume of less than $30 \%$ or haemoglobin level of less than 10 grams per decilitre in cervical cancer patients is considered anaemia that requires blood transfusion.

\section{Results \\ Biosocial factors}

During the study period, 70 cases of cervical cancer were managed. Majority of them (53.62\%) were Hausa, $11.59 \%$ were Fulani, and $8.70 \%$ were Idoma. Most of the patients $(83.29 \%)$ had no personal source of income (housewives - 57.53\%, widows and divorcees with no occupation - 25.76\%). The rest were in low income occupations including petty trading, farming, cleaning and local alcohol brewing.

Table 1 shows some of the biological characteristics of the patients.

\begin{tabular}{|l|l|l|}
\hline & $\begin{array}{l}\text { Mean } \\
\text { deviation) }\end{array}$ & Range \\
\hline Age at presentation & 47.61 years $(11.55)$ & 28 to 72 \\
\hline Age at first coitus & 14.62 years $(2.65)$ & 11 to 22 \\
\hline Parity & $7.40(3.42)$ & 0 to 15 \\
\hline Last menstrual period & 71.50 months $(87.6)$ & 0 to 360 \\
\hline Last childbirth & 158.30 months $(116.2)$ & 10 to 504 \\
\hline
\end{tabular}

The patients were mostly of high parity with parity of 8 or more being present in 34 patients $(48.57 \%)$, parity of 5 to 7 present in 21 patients $(30 \%)$, while only $14(20 \%)$ had a parity of $1-4$, and one patient $(1.43 \%)$ had a parity of 0 . Most of the patients were married $(71.01 \%)$ while $21.74 \%$ were widowed and $7.25 \%$ were divorced. The marriage was monogamous in 9 cases $(18.37 \%)$ and polygamous in 40 cases $(81.63 \%)$. Among the patients, 31 (53.45\%) had been married only once, 20 (34.48\%) had been married twice, $4(6.90 \%)$ had been married thrice, 2 $(3.45 \%)$ had been married 5 times and one $(1.72 \%)$ had been married 7 times.

Majority of the patients $(89.80 \%)$ had never used contraceptives, $2.04 \%$ had used pills in the past, $6.12 \%$ had used injectables, and $2.04 \%$ had used the IUCD in the past. Only 8 patients $(15.09 \%)$ were current or previous tobacco smokers, similarly, current or previous alcohol ingestion was present in 8 patients $(15.09 \%)$. Only 8 patients $(11.43 \%)$ resided in Zaria town, 7 of these resided within one kilometre of the hospital and one within 2 kilometres of the hospital. The distance from the patient's residence to this hospital was $0-100 \mathrm{~km}$ for 20 patients $(28.57 \%)$, $101-300 \mathrm{~km}$ for $30(42.86 \%), 301-500 \mathrm{~km}$ for 13 $(18.57 \%)$, and $501 \mathrm{~km}$ or more for $7(10 \%)$. Of all the patients, $19(27.14 \%)$ were first seen at this hospital while the remaining 51(72.86\%) were referred from other health facilities. Of those who were referred, $5(9.80 \%)$ were referred from health facilities within Zaria. The distance from the referring centre to this hospital was $1-100 \mathrm{~km}$ for 13 patients $(25.49 \%), 101-300 \mathrm{~km}$ for 26 patients (50.98\%), 301-500 km for 6 patients $(11.76 \%)$, and $501 \mathrm{~km}$ or more for 6 patients $(11.76 \%)$.

\section{Clinical factors}

The mean duration of symptoms was 12.59 months (Standard deviation $=11.84$, range $=0.25$ to 60 months). Details of the duration of symptoms and stage at presentation are shown in Table 2 .

The histological types included large cell keratinizing squamous cell carcinoma in $43.18 \%$, large cell non-keratinizing squamous cell carcinoma in $29.55 \%$, and moderately differentiated adenocarcinoma in $4.55 \%$. Other types included mucinous adenocarcinoma, well-differentiated adenocarcinoma, small cell non-keratinising (epidermoid), and adenosquamous carcinoma $2.27 \%$ each. The specific histological type was not mentioned in $13.64 \%$ but were said to have squamous cell carcinoma in the histology reports. 
Table 2: Duration of symptoms and stage at presentation

\begin{tabular}{|l|l|l|l|}
\hline Duration of symptoms & Number (\%) & Stage at presentation & Number (\%) \\
\hline$<6$ months & $20(29.41)$ & IA & $0(0)$ \\
\cline { 3 - 4 } & & IB & $3(4.35)$ \\
\hline \multirow{2}{*}{$6-11$ months } & \multirow{2}{*}{$(25)$} & IIA & $6(8.70)$ \\
\cline { 3 - 4 } & & IIB & $14(20.29)$ \\
\hline \multirow{2}{*}{$12-23$ months } & \multirow{2}{*}{$(27.94)$} & IIIA & $6(8.70)$ \\
\cline { 3 - 4 } & & IIIB & $21(30.43)$ \\
\hline \multirow{2}{*}{$\geq 24$ months } & IVA & $13(18.84)$ \\
\cline { 3 - 4 } & & IVB & $5(7.25)$ \\
\hline & & Recurrent & $1(1.45)$ \\
\hline
\end{tabular}

Admission rate was $31.34 \%$ and of those that were admitted, $36.36 \%$ were on admission for less than 14 days and $63.64 \%$ were on admission for 14 or more days. The mean duration of admission was 8.73 days (Standard deviation $=17.86$, range $=0$ to 60 days). Of those who were admitted for 14 days or more, $71.43 \%$ stayed for that duration due to lack of funds and/or blood for transfusion, $14.29 \%$ were awaiting intravenous urography, and $14.29 \%$ had nowhere to stay in Zaria.

Although the mainstay of treatment is radiotherapy for these late stages of cervical cancer, only $34.29 \%$ of these patients had full course of radiotherapy, $4.29 \%$ had incomplete radiotherapy while $2.86 \%$ were unfit for radiotherapy. Others did not have any therapy at all as they defaulted. The default rate was very high with $69.57 \%$ of the patients defaulting from the hospital, while $2.90 \%$ discharged themselves against medical advice and were not seen again, $1.45 \%$ discharged themselves, $1.45 \%$ died in hospital, and $2.90 \%$ were referred to centres closer to their homes upon their request. Patients who received complete treatment constituted $21.74 \%$, most $(86.67 \%)$ of who are still being followed-up in the clinic. Of those who defaulted, $25.93 \%$ did so after the first visit to the hospital, $12.96 \%$ after the second visit, $27.74 \%$ after 3 or more visits, $18.52 \%$ after radiotherapy, $9.26 \%$ after admission, and $5.56 \%$ during radiotherapy.

Anaemia requiring blood transfusion was present in 24 patients $(34.29 \%)$, of these, the deficit in the packed cell volume required transfusion of one unit of blood in 4 patients $(16.67 \%)$, two units in 6 $(25 \%)$, three units in $10(41.67 \%)$, four units in two $(8.33 \%)$, and five units in two patients $(8.33 \%)$. The number of units of blood required to correct the anaemia was transfused in $25 \%$ of those who needed blood transfusion while the transfusion was inadequate by 1 unit for 7 patients $(29.17 \%), 2$ units for 6 patients (25\%), 3 units for 4 patients $(16.67 \%)$, and 4 units in 1 patient $(4.17 \%)$. The mean units of blood required was 1.12 (Standard deviation $=1.51$, range $=0$ to 5) whereas the mean units of blood transfused was 0.52 (Standard deviation $=0.93$, range $=0$ to 3 )

Defaulting was not significantly associated with the patient's age, parity, last menstrual period, last childbirth, duration of symptoms, distance from the patient's residence or the distance from the referring centre as shown in Table 3. There was also no significant association between defaulting and having a personal income $\left(\chi^{2}=0.98, p=0.32\right)$.

\section{Discussion}

The mean age of the patients was 47.61 years which is similar to previous reports from Zaria $[2,10]$ and other parts of sub-Saharan Africa [3,6]. This is earlier than the mean age at presentation in developed countries and has been attributed to the earlier age at marriage and thus sexual exposure in this environment [10]. This is supported by the fact that the age at first sexual exposure is low (mean $=14.62$ years), a recognized risk factor for the development of cervical cancer. Other known risk factors that were present in this group of women included high parity (mean $=7.4)$ and low contraceptive prevalence $(10.20 \%)$, multiple sex partners (polygamous marriages in $81.63 \%$ of cases and multiple marriages in $42.55 \%$ ), and smoking $(15.09 \%)$. Similar risk factors were reported in earlier studies [7, 10] and highlight the need for well-designed public awareness campaigns.

Majority of the patients presented late - the mean duration of symptoms before presentation was 12.59 months and there was no patient who presented with stage IA disease while only $4.35 \%$ presented with stage IB disease. This is another factor that negatively impacts on the outcome of management of the condition as treatment is more effective in early stages of the disease [1]. This issue can only be 
addressed through raising public awareness of the

early treatment.

signs and symptoms of the disease and the need for

Table 3: Relationship between patients' characteristics and defaulting from hospital

\begin{tabular}{|c|c|c|c|c|}
\hline Factor & Defaulted (means) & Did not default & Difference & 95\% CI (p value) \\
\hline $\begin{array}{ll}\begin{array}{l}\text { Distance } \\
\text { hospital }\end{array} & \\
\text { (residence) } & \end{array}$ & 222 kilometres & 333 kilometres & 111 kilometres & $\begin{array}{l}-283.10 \\
(0.19)\end{array}$ \\
\hline $\begin{array}{l}\text { Distance from } \\
\text { hospital } \\
\text { (referring centre) }\end{array}$ & 164 kilometres & 262 kilometres & 98 kilometres & $\begin{array}{l}-282.00, \\
(0.27)\end{array}$ \\
\hline Age & 48.30 years & 47.20 years & 1.10 years & $-6.77,8.84(0.78)$ \\
\hline Parity & 7.45 & 7.62 & 0.17 & $-2.59,2.25(0.88)$ \\
\hline $\begin{array}{ll}\text { Last menstrual } \\
\text { period }\end{array}$ & 77.60 months & 57.60 months & 20 months & $\begin{array}{l}-34.70, \\
(0.46)\end{array}$ \\
\hline Last childbirth & 167 months & 128.70 months & 38.30 months & $\begin{array}{ll}-34.70, & 111.00 \\
(0.28) & \\
\end{array}$ \\
\hline $\begin{array}{l}\text { Duration } \\
\text { symptoms }\end{array}$ & 12.06 months & 19.70 months & 7.64 months & $-21.5,4.28(0.17)$ \\
\hline
\end{tabular}

Lack of funds for investigations and treatment was also a risk factor for poor prognosis as only $25 \%$ of the 24 patients who needed blood transfusion were adequately transfused and only $21.74 \%$ of all patients had complete treatment. Lack of funds also contributed to unnecessarily prolonged hospital stays that further deplete financial resources. The default rate was very high among these patients but defaulting was not significantly associated with the patient's age, duration of symptoms, distance from the patient's residence or the distance from the referring centre. This suggests other factors, most likely financial, influence the patient's decision not to return to the hospital for continued care although there was no significant association between defaulting and having a personal income probably because most women in this environment rely on their husbands or parents for payment of hospital bills.

Cervical cancer management services need to be available, accessible and affordable to those who need them before any meaningful reduction in the impact of cervical cancer in developing countries can be achieved. The possibility of offering hypofractionated radiotherapy is an option that has been suggested as a way of tackling the problem of too few services [9] but there is also a need to consider subsidizing the cost of radiotherapy as well as increasing the number of facilities that offer the services. Governments and other funding agencies need to devote more funds for the management of this disease including prevention strategies and screening programs.

\section{References}

1. Cervical cancer control in developing countries: memorandum from a WHO meeting. Bulletin of the World Health Organisation. 1996; 74: 345-351.

2. Emembolu JO and Ekeme CG. Cancer of the cervix uteri in Zaria - Aetiological factors. International Journal of Gynecology and Obstetrics. 1988; 26: 265-269.

3. Briggs ND and Katchy KC. Pattern of primary gynecological malignancies as seen in a tertiary hospital situated in the Rivers State of Nigeria. International Journal of Gynecology and Obstetrics. 1990; 31:157161.

4. Babarinsa IA, Akang EEU and Adewole IF. Pattern of Gynaecological Malignancies at The Ibadan Cancer Registry (1976-1995). Nigerian Quarterly Journal of Hospital Medicine. 1998; 8: 103-106.

5. [5] Armon PJ and Missalek W. Carcinoma of the cervix in Tanzania. East African Medical Journal 1978; 55: 534-537.

6. Ojwang SBO and Mati JK. Carcinoam of the cervix in Kenya. East African Medical Journal 1978; 55: 194-198.

7. Rostad B, Schei B and da Costa F. Risk factors for cervical cancer in Mozambican women. International Journal of Gynecology and Obstetrics. 2003; 80:63-65.

8. Tobias JS. The role of radiotherapy in the management of cancer - an overview. Annals of the Academy of Medicine of Singapore. 1996; 25: 371-379. 
9. Campbell OB, Akinlade IB, Arowojolu A, Babarinsa IA, Agwimah RI, and Adewole IF. Comparative evaluation of hypofractionated radiotherapy and conventional fractionated radiotherapy in the management of carcinoma of the cervix in Ibadan, Nigeria. African Journal of
Medicine and Medical Sciences. 2000; 29: 253-258.

10. Rafindadi AH, Ifenne DI, Shittu SO, Bako AU and Olasinde TA. A study of some aetiological factors in 41 cases of cancer of the cervix uteri in Zaria. Nigerian Quarterly Journal of Hospital Medicine. 1999; 9:8789. 